\title{
院内製剤ウリナスタチン臸坐剤の物理薬剤学的特性
}

\author{
佐竹 清, ${ }^{*, a, b}$ 中島孝則, ${ }^{b}$ 岩田政則, ${ }^{c}$ 藤掛佳男, ${ }^{a}$ 木村正幸 $b$
}

\section{Physicopharmaceutical Characteristics of Ulinastatin Vaginal Suppositories Prepared in Hospital}

\author{
Kiyoshi SATAKe, ${ }^{*, a, b}$ Takanori NAKAJIMA, ${ }^{b}$ Masanori IwATA, ${ }^{c}$ \\ Yoshio FUJIKAKE, ${ }^{a}$ and Masayuki KIMURA ${ }^{b}$ \\ ${ }^{a}$ Department of Pharmacy, Saitama Red Cross Hospital, Kamiochiai 8-3-33, Cyuo-ku, Saitama 338-8553, \\ Japan, ${ }^{b}$ Clinical Pharmacy Educational Center, Nihon Pharmaceutical University, Komuro 10281, \\ Ina-machi, Kita-adachi-gun, Saitama 362-0806, Japan, and 'Department of Clinical \\ Pharmaceutics, Yokohama College of Pharmacy, Matano-cho 601, \\ Totsuka-ku, Yokohama 245-0066, Japan
}

(Received May 20, 2011; Accepted August 2, 2011; Published online August 9, 2011)

\begin{abstract}
We studied a locally applied vaginal preparation (vaginal suppositories) of ulinastatin (urinary trypsin inhibitor, UTI), designed to threatened premature delivery and maintain pregnancy. Witepsol S55 was chosen as the basic component of the vaginal suppositories based on the physical pharmaceutical characteristics of three kinds of hard fats. The average particle size of the UTI aqueous injection was approximately $70 \%$ as compared with that of the UTI lyophilized product, used as the base material for the preparation of UTI vaginal suppositories. We compared the physical pharmaceutical properties of UTI vaginal suppositories with water contents of $2.5 \%, 5.0 \%$, and $7.5 \%$, respectively. Preparation strength negatively correlated with the water content. The coefficient of viscosity positively correlated with the water content of the preparation. UTI vaginal suppositories with a water content of $5.0 \%$ had the highest average drug release rate on moment analysis. A comprehensive evaluation of the properties of UTI vaginal suppositories, including high strength due to disintegration resistance, the coefficient of viscosity and its influence on local retention, and drug release and its influence on the duration of effect, indicated that a 5.0\% UTI aqueous solution for injection combined with Witepsol S55 as the base was the optimal formulation for the hospital preparation of vaginal suppositories.
\end{abstract}

Key words — ulinastatin; vaginal suppository; hospital preparation; threatened premature delivery; physicopharmaceutical characteristic

\section{緒言}

ウリナスタチン（urinary trypsin inhibitor; UTI）

は，ヒト尿中から抽出，精製された糖タンパク質で あり，白血球エラスターゼやトリプシンなど種々の 酵素に阻害作用を持ち，急性膵炎，慢性再発性膵炎 の急性憎悪期，急性循環不全の適応で臨床使用され ている. 1) 産科領域におけるUTI の局所投与は, エ ラスターゼやサイトカイン活性の阻害により頸管炎 や絨毛膜羊膜炎に対し抗炎症作用を示すことから, UTI 臸坐剂が切迫早産の治療に使用されている. 2,3 このUTI 臸坐剤には市販品がないことから，院内

$a$ さいたま赤十字病院薬剤部, ${ }^{b}$ 日本薬科大学臨床薬学 教育センター, c横浜薬科大学臨床薬剤学研究室

*e-mail: srcph@jcom.home.ne.jp
製剂として溶融法により調製されており，主薬原料 として注射用凍結乾燥製剤（凍結乾燥製剂），又は 水性注射液製剂（水性注射剂）が用いられてい る. ${ }^{4,5)}$ 凍結乾燥製剂を用いる製法は，あらかじめ乳 鉢で微粉化した薬剂を加温した坐剂基剂に加え混和 後成形するが, 本方法は調製過程において微粉砕し た薬剤が吸湿して凝塊（二次粒子）を形成し易く, 基剂中での均一な分散は困難との指摘があり，水性 注射剂を用いる製法が提案されている.5)しかしな がら，この水性注射剂を用いて調製されたUTI 腔 坐剂についての物理薬剤学的検討はなされていな い。そこで本研究では，UTI 水性注射剤と主薬原 料として種々のハードファット（ウイテプゾール） 基剤を用いた UTI 腔坐剤を調製し，種々の物理薬 剂学的特性值から最適な基剤タイプを選択するとと 
もに，薬物放出特性から院内製剤として最適な処方 を検討した.

$$
\text { 方法 }
$$

1. 試薬＼cjkstart主薬であるウリナスタチン (UTI) は，ミラクリッド注射液 5 万単位（持田製薬）（以 下，ウリナスタチン注射液と略す）を使用した。臸 坐剂の基剤としてウイテプゾール H15，-W35，-S55 (Sasol Germany GmbH) を使用した. トリプシン はウシ膵臓製生化学用（和光純薬）を， $N$ - $\alpha$-ベン ゾイル-L-アルギニン-4-ニトロアニリド塩酸塩（LBAPA）はペプチド研究所製のものを使用した。そ の他の試薬は特級品又は純度 $99 \%$ 以上のものを用 いた。

\section{UTI 腔坐剤の調製 UTI 腔坐剂（Table 1）} は溶融法により調製した。あらかじめ臸坐剤基剤を 約 $50^{\circ} \mathrm{C}$ で融解し， $45^{\circ} \mathrm{C}$ まで放冷後マグネチックス ターラーで擋挥しながら少量ずつウリナスタチン注 射液を混和した。混和物をプラスチック製坐剂コン テナに注入し，室温にて放冷固化させた後， $4^{\circ} \mathrm{C}$, 遮光下で 24 時間以上保存した。

\section{UTI 腔坐剤の評価}

3-1. 粒子の分散状態 粒子の分散状態は, 顕 微鏡法グリーン径で行った。基剤はウイテプゾール W35 を使用し, ${ }^{4)}$ OLYMPUS DP12 において試料板 として血球計算板を使用し，100 倍の倍率でランダ ムに 200 個の粒子径を測定した。

3-2. 強度 胵坐剂の破断応力はレオメータ RT-3005D（レオテック）にて測定した。融解した 臸坐剂を注射筒（ツベルクリン用 $1 \mathrm{ml}$ ，テルモ） に吸引して室温で固化させることにより，円筒形 （申4.5 mm×60 mm）の試料を調製した。試料を折 れ芯 JIS 用 No. 37 （支持台距離 $40 \mathrm{~mm}$ ）に設置し, 歯型押棒 B No. 13 にて毎分 $60 \mathrm{~cm}$ の速度で加圧し た時の破断応力を測定した。測定は 20 回行い，そ の平均值を強度とした。

Table 1. Formula of Ulinastatin Vaginal Suppositories

\begin{tabular}{cccc}
\hline \hline Formula & Ulinastatin & $\%$ & Witepsol S55 $(\mathrm{g})$ \\
\hline A & 5000 units $(0.1 \mathrm{ml})$ & 2.5 & 3.90 \\
B & 5000 units $(0.1 \mathrm{ml})$ & 5.0 & 1.90 \\
C & 5000 units $(0.1 \mathrm{ml})$ & 7.5 & 1.23 \\
\hline
\end{tabular}

Vaginal suppositories were prepared with the fusion method.
3-3. 粘度 膣坐剂の粘度はVisconic ED 型粘 度計（東京計器）を用いて測定した. 腔坐剤を 37.0 $\pm 0.5^{\circ} \mathrm{C}$ にて溶融した試料 $1.2 \mathrm{ml}$ について測定を行 い, 5 試料の平均值を粘度とした。

3-4. 熱力学的パラメータ 臸坐剤の熱力学的 パラメー夕は示差走査熱量計 DSC8230（Rigaku） を用いて測定した。測定にはアルミパンの試料血を 使用し，測定条件は，基準サンプル：酸化アルミニ ウム粉末, 試料量 : 約 $2 \mathrm{mg}$, 昇温速度 : $3^{\circ} \mathrm{C} / \mathrm{min}$, 測定温度 : $20-120^{\circ} \mathrm{C}$ にて実施した。測定は 5 回行 い, 平均值を求めた。

3-5. 薬物放出性腔坐剂の薬物放出性は，坐 剂放出試験器（村西式，富山産業）を用いて測定し た。測定条件は，セル内回転軸：25 rpm，坐剂投 入相と放出相間に設置したメンブランフィルター： WhiteSSWP ( $\phi 47 \mathrm{~mm}$ ，孔径 $3.0 \mu \mathrm{m}$, MILLIPORE), 試験液：精製水 $200 \mathrm{ml}\left(37.5 \pm 0.5^{\circ} \mathrm{C}\right)$ を用いた. 試験液は試験開始後 6 時間にわたり経時的に $2 \mathrm{ml}$ を採取するとともに，同量の精製水を補充した。

4. ウリナスタチンの定量坐剂放出試験液中 のウリナスタチン量は，第十五改正日本薬局方ウリ ナスタチン定量法に準じて測定した (Fig. 1). ${ }^{6}$ 呈 色した試料液の $405 \mathrm{~nm}$ における吸光度を UV240 形分光光度計（島津製作所）にて測定し，あらかじ め作成した検量線からウリナスタチン量を求めた.

5. 数値計算 各種パラメータの算出は, 山岡 ら7)のプログラムを応用して行った。有意差検定は， student- $t$ 検定で行った。

$\frac{\text { Sample solution 1.0ml }}{\text { or }}$ (Extracts by suppository release tester) Standard solution $1.0 \mathrm{ml}$

Add $0.1 \mathrm{ml}$ of $1 \mathrm{M}$ triethanolamine buffer, $\mathrm{pH} 7.8$ Stand for $1 \mathrm{~min}$ Add $0.05 \mathrm{ml}$ of tripsin solution Incubate for $1 \mathrm{~min}$ at $37^{\circ} \mathrm{C}$ Add $0.5 \mathrm{ml}$ of L-BAPA solution Incubate for $2 \mathrm{~min}$ at $37^{\circ} \mathrm{C}$ Add $0.05 \mathrm{ml}$ of $50 \%$ acetic acid solution

\section{Read absorbance at $405 \mathrm{~nm}$}

Fig. 1. Analytical Method for Ulinastatin Vaginal Suppositories 
結果

1. 粒度分布 UTI 胵坐剂の主薬原料として使 用した，ミラクリッド注射液 5 万単位(水性注射剂) 及びミラクリッド 5 万単位（凍結乾燥製剂）の製剂 中の分散状態を Fig. 2, 及び粒子径のヒストグラム をFig. 3 に示す。水性注射剂及び凍結乾燥製剂の 平均粒子径は $28.4 \pm 21.6 \mu \mathrm{m}$ 及び $38.7 \pm 50.7 \mu \mathrm{m}$ と なり，分散粒子間に有意な差 $(p<0.01)$ が観察さ れた。

2. 基剤の特性值 腔坐剤基剤の物理薬剤学的 特性值を Table 2 に示す。基剤の強度は，0.193$0.313 \mathrm{~kg}$ となり, ウイテプゾール S55 の強度は, ウ イテプゾール H15 の約 1.2 倍, ウイテプゾール W35 の約 2.0 倍となった。基剤の粘度は，29.9$113.9 \mathrm{cP}$ となり，ウイテプゾール S55 の粘度は, ウイテプゾール H15 の約 3.8 倍, ウイテプゾール W35 の約 2.0 倍となった。基剤のピーク温度に関 しては，3 種類の基剤間で有意な差は認められなか つた。基剤の融解熱量は，112.5-136.5 J/g とな

(A)

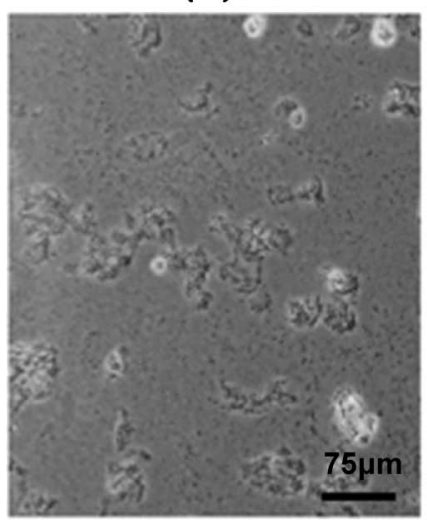

(B)

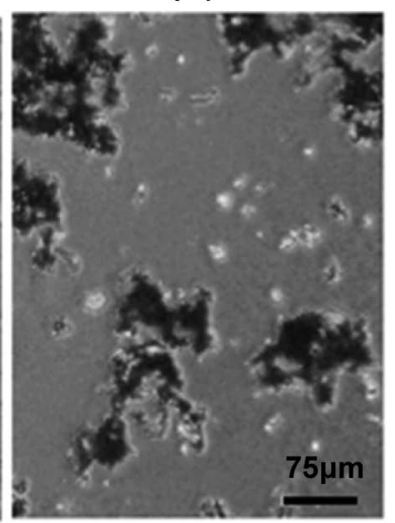

Fig. 2. Mycroscopic View of Dispersed Particles in Ulinastatin Vaginal Suppositories

A: Aqueous injection, B: Lyophilized injection.
り，ウイテプゾール H15 の融解熱量は，ウイテプ ゾール W35 及び， ウイテプゾール S55 の約 1.2 倍 となった。

\section{UTI 腔坐剤の処方と特性值}

3-1. 水分配合率と強度 ウリナスタチン注射 液を原料とした UTI 胵坐剂の強度を Fig. 4 に示 す。処方 $\mathrm{A}$ ，処方 $\mathrm{B}$ 及び処方 $\mathrm{C}$ の強度（Y2）は， $0.312 \pm 0.031 \mathrm{~kg}, \quad 0.207 \pm 0.019 \mathrm{~kg}, \quad 0.174 \pm 0.025 \mathrm{~kg}$ $(\mathrm{Y} 2=0.369-0.0276 \mathrm{X}, \mathrm{R}=0.917)$ であり，水分配 合率が増えると強度は低下する負の相関が認めら れ，水分配合率が最も低い $2.5 \%$ が最も高い值を示 した.

3-2. 水分配合率と粘度 ウリナスタチン注射 液を原料とした UTI 胵坐剂の粘度を Fig. 5 に示 す。処方 $\mathrm{A}$ ，処方 B 及び処方 C の粘度（Y3）は， $49.7 \pm 1.5 \mathrm{cP}, \quad 62.6 \pm 4.6 \mathrm{cP}, \quad 95.9 \pm 14.9 \mathrm{cP} \quad(\mathrm{Y} 3=$ $23.20+9.24 \mathrm{X}, \mathrm{R}=0.939)$ であり，水分配合率が増 えると粘度は高くなる正の相関が認められ，7.5\% が最も高い值を示した。

3-3. 水分配合率と熱力学的パラメータ ウリ ナスタチン注射液を原料とした UTI 腔坐剤のピー
(A)

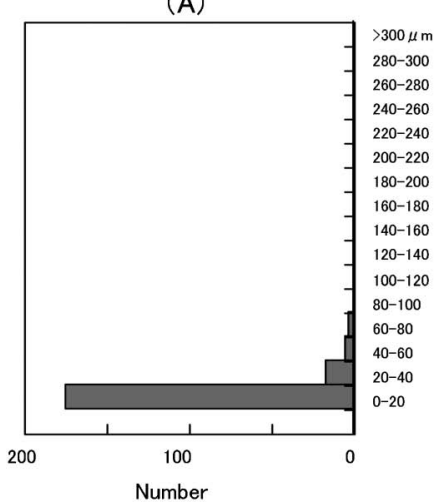

(B)

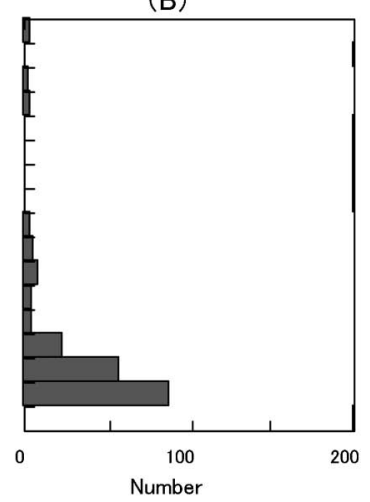

Fig. 3. Histogram of Dispersed Particles in Ulinastatin Vaginal Suppositories

A: Aqueous injection, B: Lyophilized injection.

Table 2. Characteristics of Witepsol H15, Witepsol W35 and Witepsol S55 as a Base

\begin{tabular}{lcccc}
\hline \hline & $\begin{array}{c}\text { Strength } \\
(\mathrm{kg})\end{array}$ & $\begin{array}{c}\text { Viscosity } \\
(\mathrm{cP})\end{array}$ & $\begin{array}{c}\text { Peak temp. } \\
\left({ }^{\circ} \mathrm{C}\right)\end{array}$ & $\begin{array}{c}\text { Heat of } \\
\text { fusion }(\mathrm{J} / \mathrm{g})\end{array}$ \\
\hline Witepsol H15 & $0.263 \pm 0.060$ & $29.9 \pm 0.6$ & $34.8 \pm 0.4$ & $136.5 \pm 13.0$ \\
Witepsol W35 & $0.193 \pm 0.068$ & $56.3 \pm 2.2$ & $36.1 \pm 0.4$ & $112.5 \pm 7.50$ \\
Witepsol S55 & $0.313 \pm 0.057$ & $113.9 \pm 13.1$ & $33.5 \pm 0.2$ & $115.1 \pm 14.9$ \\
\hline
\end{tabular}

a Sample size: $\phi 4.5 \mathrm{~mm} \times 40 \mathrm{~mm}$, Press speed: $60 \mathrm{~cm} / \mathrm{min} .{ }^{b}$ Sample temperature: $37.0^{\circ} \mathrm{C}$. Each datum represents mean \pm S.D. 


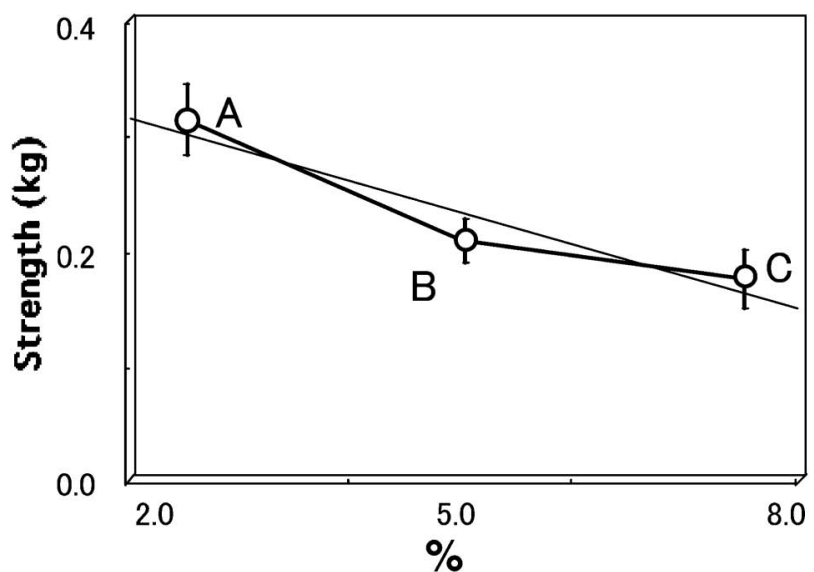

Fig. 4. Relation between Strength and Percent of Ulinastatin in Suppositories

Each point represents the mean \pm S.D., $n=20$.

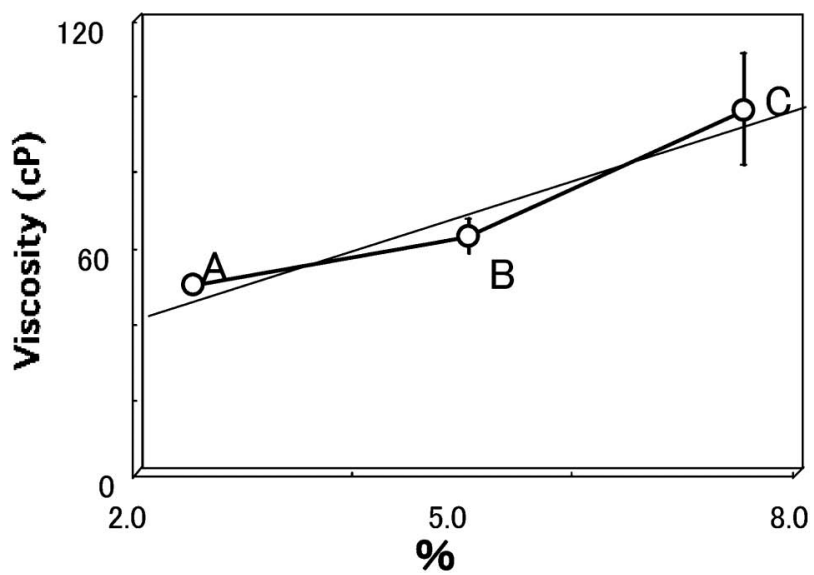

Fig. 5. Relation between Viscosity and Percent of Ulinastatin in Suppositories

Each points represents the mean \pm S.D., $n=5$.

ク温度及び融解熱量を Fig. 6 に示す。処方 A，処 方 $\mathrm{B}$ 及び処方 $\mathrm{C}$ のピーク温度（Y4）は， $33.8 \pm 0.3$ ${ }^{\circ} \mathrm{C}, 28.7 \pm 0.2{ }^{\circ} \mathrm{C}, 28.9 \pm 0.1{ }^{\circ} \mathrm{C}$ となり, $2.5 \%$ 配合率 である処方 A が最も高い值を示した。融解熱量 （Y5）は, $135.3 \pm 12.4 \mathrm{~J} / \mathrm{g}, 121.2 \pm 9.3 \mathrm{~J} / \mathrm{g}, 120.0 \pm$ $9.6 \mathrm{~J} / \mathrm{g}$ となり，2.5\%配合率である処方 $\mathrm{A}$ が最も高 い值を示した.

4. UTI 腔坐剤からの薬物放出性に対する水分配 合率の影響ＵTI 臸坐剂からの経時的な薬物放 出パターンを Fig. 7 に示す。時間の経過とともに 臸坐剤からはUTI が放出された。 $2.5 \%, 5.0 \%$ 及び $7.5 \%$ 含有臸坐剂からの 6 時間後の UTI 濃度は, $1.85 \pm 0.41 \mu \mathrm{g} / \mathrm{ml}, 13.19 \pm 2.17 \mu \mathrm{g} / \mathrm{ml}$ 及び $17.60 \pm$ $1.10 \mu \mathrm{g} / \mathrm{ml}$ となった.
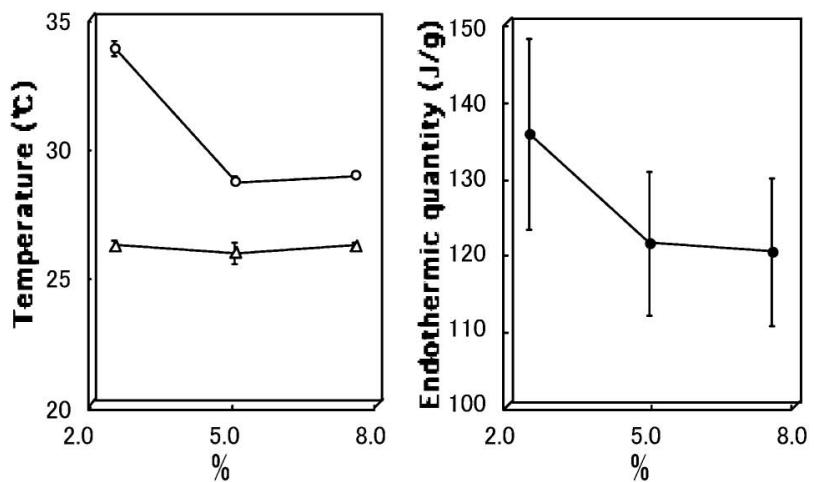

Fig. 6. Relation between Thermodynamic Parameters and Percent of Ulinastatin in Suppositories

$\bigcirc$ : Peak temperature, $\triangle$ : Melting point, $\bigcirc$ : Heat of fusion. Each points represents the mean \pm S.D., $n=5$.
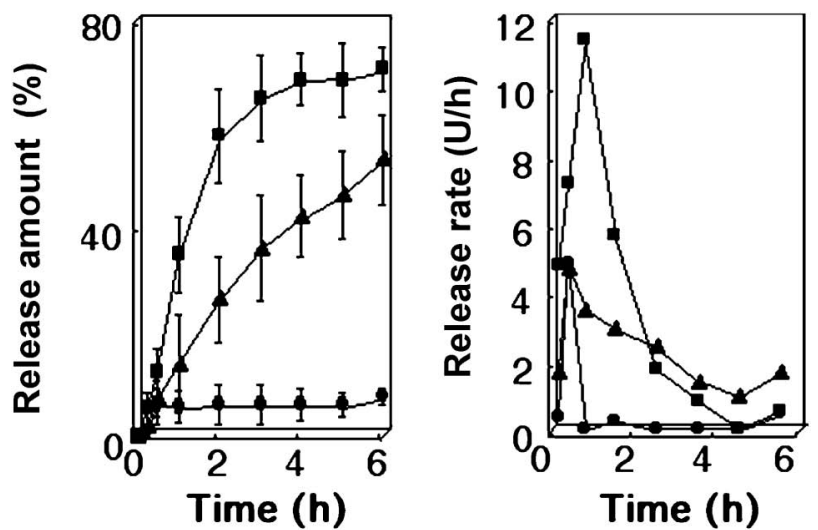

Fig. 7. Time Cource Changes in Release Amount and Rate of Ulinastatin from Suppositories

-: Formula A, $\mathbf{\Delta}$ : Formula B, $\mathbf{\square}$ : Formula C. Each points represents the mean \pm S.D., $n=6$.

モーメント解析で得られた $2.5 \%, 5.0 \%$ 及び 7.5 $\%$ UTI 腔坐剂の薬物放出速度一時間曲線下面積 （ADT）の平均值は， $1.91 \mu \mathrm{g} \cdot \mathrm{h} / \mathrm{ml}, 12.5 \mu \mathrm{g} \cdot \mathrm{h} / \mathrm{ml}$, $17.5 \mu \mathrm{g} \cdot \mathrm{h} / \mathrm{ml}$ となった. また, 薬物平均放出速度 （MDT）は，5.0\%配合率が 2.16 時間となり，他の 製剤に比べて高い值を示した.

ウリナスタチン注射液の添加率及び UIT 胵坐剂 の各特性值間の単相関行列を Table 3 に示す。膣坐 剂中の水分配合率は, 腔坐剂の特性值との間に相関 性が観察された.

\section{考察}

凍結乾燥製剂を用いた臸坐剂中の UTI 分散粒子 は，二次凝集体を形成し，平均粒子径は $38.7 \pm 50.7$ $\mu \mathrm{m}$ となり，水性注射剂を使用して調製したときの 
Table 3. Simple Correlation Matrix among Characteristics

\begin{tabular}{lcccccc}
\hline \hline & Y1 & Y2 & Y3 & Y4 & Y5 & Y6 \\
\hline Ulinastatin \% (Y1) & 1.000 & 0.917 & 0.939 & 0.719 & 0.808 & 0.961 \\
Strength (Y2) & & 1.000 & 0.734 & 0.931 & 0.974 & 0.991 \\
Viscosity (Y3) & & & 1.000 & 0.478 & 0.582 & 0.813 \\
Peak Temp. (Y4) & & & & 1.000 & 0.989 & 0.876 \\
Heat of fusion (Y5) & & & & 1.000 & 0.936 \\
ADT (Y6) & & & & & & 1.000 \\
\hline
\end{tabular}

$28.4 \pm 21.6 \mu \mathrm{m}$ に比べて約 1.4 倍となった．水性注 射剂を原料とする臸坐剤のUTI 粒子の変動係数は 0.76 となり, 凍結乾燥製剤を原料とする腔坐剤の 1.31 より小さい值となることから，水性注射剂を 原料とする腔坐剂の方が均一な粒子を有する製剤で あると言える，上村ら ${ }^{5)}$ は，従来の凍結乾燥製剂を 粉砕・混合する製法が調製時のバイアルや器具への 付着することを報告した．筆者らの検討結果は，水 性注射剂と基剤を直接混合した UTI 腔坐剂が優れ た製剤が得られることを裏付けるものと言える.

UTI 腔坐剂の基剤として, ウイテプゾール H15, -W35, -S55の 3 種類について物理薬剤学的特性值 を比較検討した（Table 2)。強度に関しては，坐剂 コンテナからの取り出し易さ，手による挿入性など の利便性を考慮したものである，また，粘度に関し ては，UTI 膣坐剤の使用法が 1 日 1 回ということ から, 粘膜付着性による局所滞留性を期待する指標 とした。 ウイテプゾール S55 が強度や粘度が高い 值であったことから，UTI 腔坐剤の基剤として 3 種類の基剤の中では最も優れていると判断した. 熱 力学的パラメータであるピーク温度や融解熱量は, 投与部位である腔内における融解性を示す指標であ り, ピーク温度は 3 種の基剤間でウイテプゾール H15, -W35, -S55 それぞれに有意差があった（ $p<$ 0.005)。融解熱量は, ウイテプゾール H15 と-W35 の間と, ウイテプゾール H15 と-S55 の間に有意差 があったが $(p<0.05)$, ウイテプゾール W35 と -S55 の間に有意差はなかった。従来, UTI 腔坐剂 の基剤としてウイテプゾール W35 が用いられてき た. ${ }^{4)}$ 筆者らは, 基剤中への分散性や基剤の特性值 の測定結果から界面活性剤を含有するウイテプゾー ル S55 が水性注射剤の混合に適した基剤であると 判断した。 また，調製過程において，ウイテプゾー ルと水性注射剂との間で二層の分離は観察されなか
つたことから，水分の除去工程は実施する必要がな いと判断した.

腔坐剤中の主薬原料量をウリナスタチン注射液 （1 アンプル）に固定し，水分配合率の特性值への 影響について検討した。製剤中の水分配合率 $2.5 \%$, $5.0 \%$ 及び $7.5 \%$ の腔坐剂を調製し，強度，粘度，熱 力学的パラメータ及び薬物放出性について検討し た．製剤中の水分配合率は，腔坐剤の特性值に対し て相関性が観察された（Table 3)。強度に関して は，水分配合率が増すと強度は低下することが判明 した。これは，油相であるウイテプゾール S55 に 対する水相であるUTI 水溶液配合率が増すにした がい，二相間の接触が増加して崩壊性が増したため と推察される。また，水分配合率が高くなると粘度 は増加した。これは, 油相である分散媒間の空隙部 が増大したことにより水相の分散粒子の摩擦抵抗が 増大したためと考える。薬物放出性に関して，異な る水分配合率の胵坐剂間で薬物放出総量に差がみら れた，放出液中への薬物放出速度は，試験開始直後 に高い值を示し，その後低下する傾向を示した (Fig. 7)。モーメント解析より得られた $2.5 \%, 5.0$ $\%, 7.5 \%$ 腔坐剂の薬物放出速度-時間曲線下面積 (ADT) は, $1.91 \mu \mathrm{g} \cdot \mathrm{h} / \mathrm{ml}, 12.5 \mu \mathrm{g} \cdot \mathrm{h} / \mathrm{ml}, 17.5 \mu \mathrm{g} \cdot \mathrm{h}$ $/ \mathrm{ml}$ であった。 $5.0 \%$ 腔坐剂は徐放性を示し，平均 放出速度（MDT）は 7.5\%胵坐剂の約 1.7 倍となつ た。腔坐剤中の水分配合率と粘度, ADT の間には 正の相関性があり，重相関係数は，0.939 及び 0.961 であった。 また, 強度, ピーク温度, 融解熱 量との間には負の相関性を示し, 重相関係数は 0.917, 0.719,0.808 であった。 以上の結果を考慮す ると, $2.5 \%$ 腔坐剂は, 強度は高いものの薬物放出 性においては放出速度が低く, 他の腔坐剂と比較し て投与部位における薬物濃度が問題となると思われ る。また, $7.5 \%$ 腔坐剤は, 粘度は高いものの強度 が低く, 急激で一過性の薬物放出性が認められた。

$5.0 \%$ 腔坐剂は, 強度も粘度も他の水分配合率の中 間に位置するが，薬物放出性において $7.5 \%$ 腔坐剂 よりも徐放性が認められる。産婦人科領域における 腔坐剂の特性を考慮したとき，崩壊性が低く，局所 滞留性に優れ，徐放性を有するものが求められ る. ${ }^{8-10)}$ 院内製剤としての使用目的や使用法を考慮 し総合的に判断すると, UTI 膣坐剤の基剤にはウ イテプゾール S55, 水分配合率 $5.0 \%$ が最適である 
と考える.

謝辞本研究にあたり，ご指導並びにご協力頂 いた，さいたま赤十字病院薬剤部諸氏に深謝いたし ます。

\section{REFERENCES}

1) Kanayama N., Maradny E. E., Halim A., Maehara K., Kajiwara Y., Terao T., Eur. J. Obstet. Gynecol. Reprod. Biol., 60, 181-186 (1995).

2) Adachi T., Acta Obstet. Gynaecol. Jpn., 58, N-161-167 (2006).

3) Kanayama N., Khatun S., Terao T., Trophoblast Res., 13, 415-425 (1999).

4) Japanese Society of Hospital Pharmacists "Byoin Yakkyoku Seizai, 5th Edition," YAKUJI NIPPO LIMITED, 2003, p. 206.

5) Kamimura M., Ueda A., Kurita H., Owada
K., Ishikawa M., Watanabe M., Fujiwara A., Yamamoto M., Kashiwagi M., Miwa N., Minami S., Iwasaki T., Nabeta I., Kuromi M., Ukishima Y., Misaki Y., Jpn. J. Pharm. Health Care Sci., 33, 775-780 (2007).

6) "The Japanese Pharmacopoeia, Fifteenth Edition," Hirokawa Publishing Co., Tokyo, 2006, pp. 901-905.

7) Yamaoka K., "Maikonniyoru Yakubutsu Tainai Dotai Kaisekiho," Nankodo Co., Ltd., 1984, pp. 145-184.

8) Masuda H., Sumiyoshi Y., Shiojima Y., Suda T., Kikyo T., Iwata M., Fujiyama N., Machida Y., Nagai T., Cancer, 48, 1899-1906 (1981).

9) Iwata M., Machida Y., Masuda H., Nagai T., Drug Des. Deliv., 1, 253-260 (1987).

10) Iwata M., Shirotake S., Hirahara F., Minaguchi K., Machida Y., Nagai T., Yakuzaigaku, 53, 148-154 (1993). 